Life Sciences Contribution

Royal Ontario Museum

Electrophoretic Patterns of Serum Proteins of Neotropical Bats (Chiroptera)

Dario Valdivieso and J. R. Tamsitt

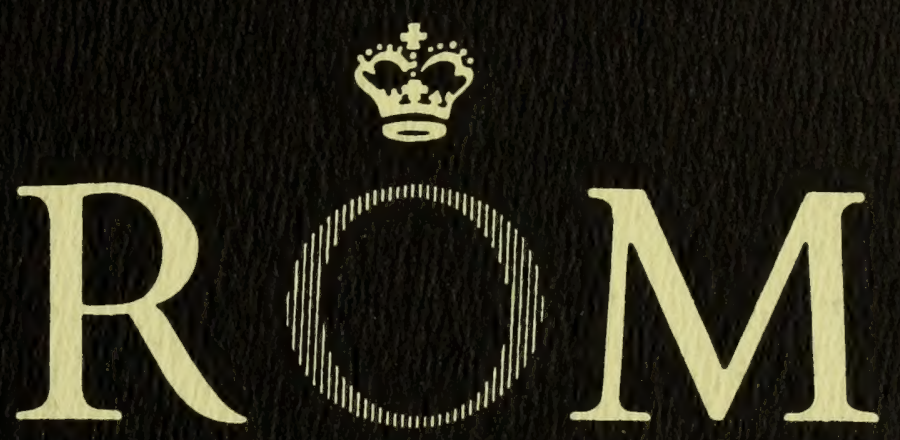


Digitized by the Internet Archive in 2011 with funding from University of Toronto 
LIFE SCIENCES CONTRIBUTIONS

ROYAL ONTARIO MUSEUM

NUMBER 98

$\begin{array}{ll}\begin{array}{ll}\text { DARIO VALDIVIESO, } \\ \text { J. R. TAMSITT }\end{array} & \text { Electrophoretic Patterns } \\ & \text { of Serum Proteins of } \\ & \text { Neotropical Bats (Chiroptera) }\end{array}$

Publication date: 10 April, 1974

ISBN: $0-88854-153-8$

Suggested citation: Life Sci. Contr., R. Ont. Mus. 


\section{ROYAL ONTARIO MUSEUM PUBLICATIONS IN LIFE SCIENCES}

The Royal Ontario Museum publishes three series in the Life Sciences:

LIFE SCIENCES CONTRIBUTIONS, a numbered series of original scientific publications, including monographic works.

LIFE SCIENCES OCCASIONAL PAPERS, a numbered series of original scientific publications, primarily short and usually of taxonomic significance.

LIFE SCIENCES MISCELLANEOUS PUBLICATIONS, an unnumbered series of publications of varied subject matter and format.

All manuscripts considered for publication are subject to the scrutiny and editorial policies of the Life Sciences Editorial Board, and to review by persons other than Museum staff who are authorities in the particular field involved.

\section{LIFE SCIENCES EDITORIAL BOARD}

Chairman: R. L. PETERSON

Editor: D. BARR

Associate Editor: J. C. BARLOW

Associate Editor: J. R. TAMSITT

DARIO VALDIVIESO is Research Associate in the Department of Mammalogy, Royal Ontario Museum.

J. R. TAMSITT is Curator in the Department of Mammalogy, Royal Ontario Museum, and Associate Professor in the Department of Zoology, University of Toronto.

PRICE: $\$ 1.25$

(C) The Royal Ontario Museum, 1974

100 Queen's Park, Toronto, Canada

PRINTED AT JOHN DEYELL COMPANY 


\title{
Electrophoretic Patterns of Serum Proteins of Neotropical Bats (Chiroptera)
}

\begin{abstract}
Serum proteins of 18 species of neotropical Chiroptera were separated by cellulose polyacetate electrophoresis. Except for differences between non-parous, adult, and gravid females in relative quantities of fractions in the alpha globulin region, resulting electropherograms were independent of sex and age. Albumin and gamma globulin fractions were monomorphic, but polymorphism in fractions of the alpha and beta globulin regions occurred in six species of Colombian and Venezuelan bats and in one species of Puerto Rican bat. Of the species studied, the insular Artibeus jamaicensis presented the most intraspecific variation. Species differed in numbers and mobilities of protein fractions. The electropherogram of Pteronotus parnellii (Mormoopidae) was not unique, whereas Phyllostomus hastatus and P. discolor (Phyllostomatinae) were not only distinct from other Phyllostomatidae but differed significantly from each other. Electropherograms of bats of the families Vespertilionidae and Molossidae were similar to each other and also, among the Phyllostomatidae, to two species of Glossophaginae, three species of Stenoderminae, and one species of Phyllonycterinae. Electrophoretic properties of serum proteins are taxonomically important but may have limited value as indicators of phylogenetic relationships. [Chiroptera; serum proteins; electrophoresis; systematics.]
\end{abstract}

\section{Introduction}

Previous work with bats has demonstrated the feasibility of correlating biochemical traits with systematic relationship. Manwell and Kerst (1966), Valdivieso et al. (1969), Tamsitt and Valdivieso (1969), and Mitchell (1970) found hemoglobin differences among species of bats to be minor but useful in estimating phylogeny at the subfamilial and familial levels. Manwell and Kerst (1966) and Valdivieso et al. (1968) found a number of differences at the generic level in lactate dehydrogenase isoenzymes, esterases, and tissue proteins, as well as ontogenetic and sexual differences and some polymorphism. Few researchers, however, have considered electrophoretic properties of bat sera as an adjunct to chiropteran classification. In a survey of serum proteins among many species of mammals, including bats of the families Vespertilionidae and Molossidae (number and taxa unspecified), Johnson and Wicks $(1959,1964)$ found that standard 
patterns for species could be established and that most significant differences occurred at the generic and specific levels. Comparisons of total protein patterns, although less valid than comparisons of single, homologous proteins, provide reliable taxonomic data for amphibians (Coates, 1967), for example, and may be useful for taxonomic classification of mammals (Feeney and Allison, 1969).

Our major objectives were to compare species by a priori taxonomic arrangement (Koopman and Jones, 1970) and to evaluate the potential of these proteins as a tool for systematic analysis. Other objectives were to determine, where possible, individual variation within samples from single populations of a species, geographic variation between populations of the same species from different localities, and to determine the effect of age, sex, and reproductive condition on electrophoretic patterns of serum proteins.

A major limitation of this study was variability of sample size for most taxa. As the acquisition of specimens more often than not was fortuitous, some species were represented by one, others by only a few specimens. Although a single sample or a low number of individuals from a population may not reveal polymorphisms, we nonetheless present all data for comparison on the premise that limited data are preferable to none. In no way do we attempt here to "characterize" a species from only one or a few samples to eschew the stigma of the typological concept (Rasmussen, 1969).

\section{Materials and Methods}

Sera were obtained from 75 bats of 18 species collected in Colombia, Puerto Rico, and Venezuela in November and December 1968, January 1969, and March and April 1970 (Table I). Bats were captured in culverts, from caves, and in "mist" nets set across trails, streams, or other flight pathways. Shortly after capture, bats were weighed, and biological data, including species, sex, reproductive condition, and age, were recorded. State of maturity was assessed from the measurement of the forearm (Handley, 1959: 98), from characteristics of pelage, and by degree of epiphysial closure of wing bones. None of the bats collected displayed gross abnormalities, and all were included in the study. After blood was taken, bats were preserved to verify field identifications. All specimens were deposited in the Department of Mammalogy, Royal Ontario Museum.

Satisfactory samples of bat sera for electrophoretic separation of protein fractions were often not easy to obtain. Moreover, although serum was obtained easily from some bats, others that were handled identically yielded blood that hemolyzed. Hemolysis of the blood of one group, the free-tailed bats of the family Molossidae, was so rapid that it was extremely difficult to obtain usable sera. In one sample of Molossus fortis from Puerto Rico, for example, blood drawn from 13 bats yielded only four usable serum samples. As the electrophoretic pattern of hemolyzed samples typically resulted in the presence of an extra, heavily-stained fraction in the beta globulin region, pinkish or reddish sera were discarded. 
Whole blood, obtained by heart puncture with sterile syringes from lightly etherized animals, was transferred to $5 \mathrm{ml}$ centrifuge tubes and left at room temperature for 2 hours to allow erythrocytes to clot. Blood was then centrifuged at 3,000 rpm for 10-15 minutes to separate serum from the clotted erythrocytes. Sera were analyzed immediately after separation or frozen at $-20^{\circ} \mathrm{C}$. Before electrophoresis, frozen samples were thawed, shaken with half volume of ether, and centrifuged at 3,000 rpm for 20 minutes to extract fats and improve electrophoretic resolution. Characteristic mobilities of serum proteins after electrophoresis were stable after cold storage, and patterns were reproducible after a month or longer.

Although a variety of electrophoretic techniques exist to analyze serum proteins, we chose cellulose polyacetate (Nerenberg, 1966) rather than disc gel, acrylamide gel, or comparable high-resolution techniques because it is less affected by physiological and environmental variables and consequently is suited for survey purposes (see, for example, Dessauer and Fox, 1964; Huntsman, 1970). Sera were analyzed by electrophoresis in the Model R-101 Microzone Cell (Beckman Instrument Co., Fullerton, California) with Sepraphore III polyacetate membranes (Gelman Instrument Co., Ann Arbor, Michigan) and barbital buffer $\mathrm{pH} 8.6$, ionic strength 0.075. The sample $(0.25 \mu 1)$ was applied to the membrane with a Beckman applicator, and separation was accomplished at $250 \mathrm{~V}$ for 20 minutes. Normal human serum (NHS) was run simultaneously with bat sera as a standard. After electrophoresis, serum proteins were stained with Ponceau $S$ (Gelman Instrument Co.). Membranes were cleared in glacial acetic acid and absolute methanol as recommended by the Gelman Instrument Co. (1968). Transparent membranes were scanned optically in a Beckman Microzone Densitometer, Model R-110, or a Spinco Analytrol, Model RB (Beckman Instrument Co.), for the integration of protein fractions. Percentages of serum proteins were calculated from resultant densitometric tracings (Beckman Instrument Co., 1967). When sufficient sera were available, total protein concentrations were determined by an adaptation of the methods of Kingsley (1939) and Gornall et al. (1949) for small quantities as suggested by the Beckman Instrument Co. (1962). Relative mobilities of albumin were calculated as the distance on the densitometric tracing (in centimetres) from the origin to the centre of the peak divided by the distance (in centimetres) from the origin to the centre of the peak of human albumin $(15.0 \pm 1.0 \mathrm{~cm})$. Relative mobilities of globulins were not calculated because of difficulties in differentiating between proximal or juxtaposed fractions. The nomenclature of globulins was established in relation to their positions as compared to those of human serum globulins. Means $(\overline{\mathrm{X}})$, standard errors (SE), and Student's $t$-tests were performed on an Olivetti-Underwood Programma 101 (Olivetti Underwood Co., New York, N.Y.) using programs devised for small samples, n-1 (Sokal and Rohlf, 1969). The sequence and nomenclature of taxa given here follow that of Koopman and Jones (1970) and Smith (1972). 


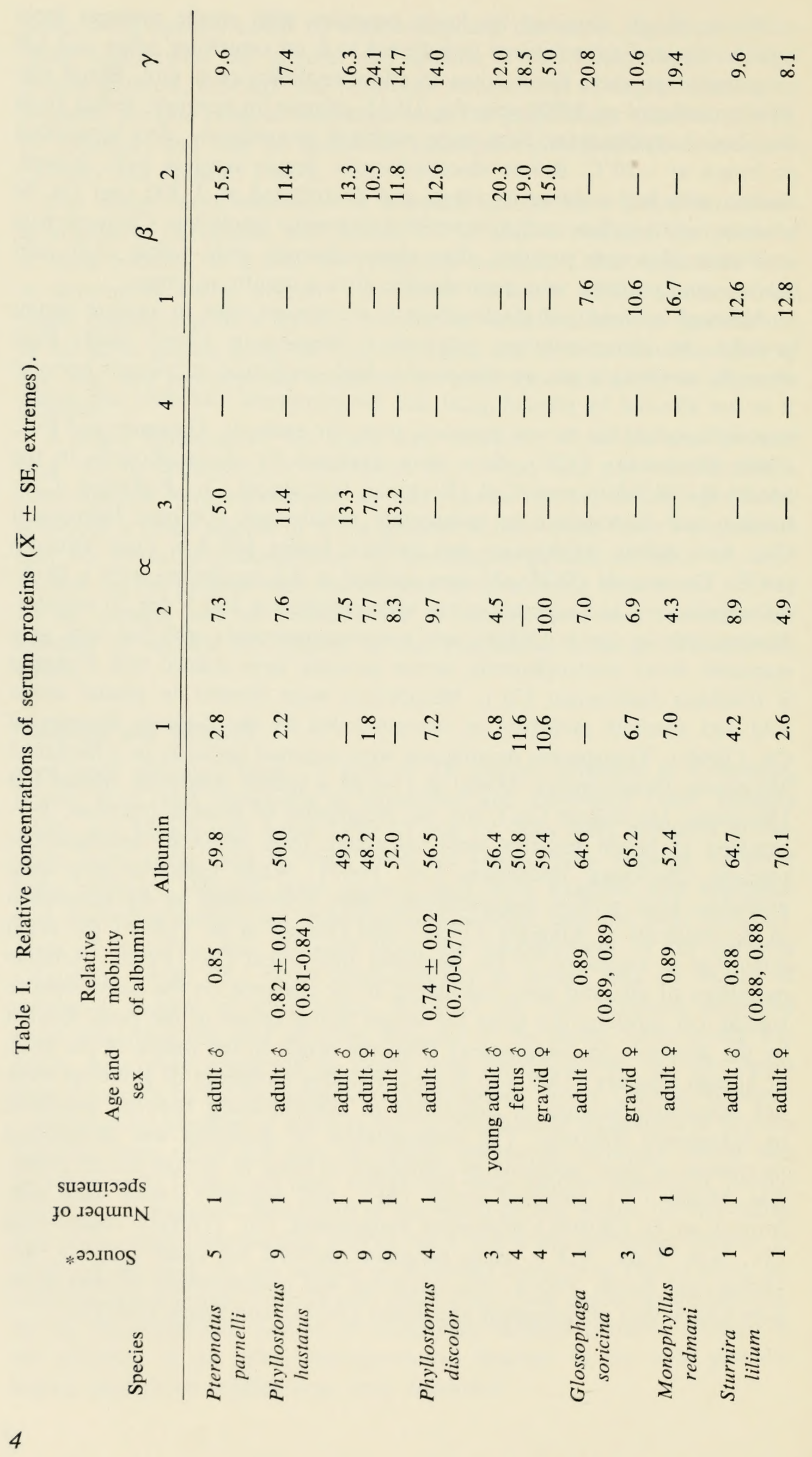




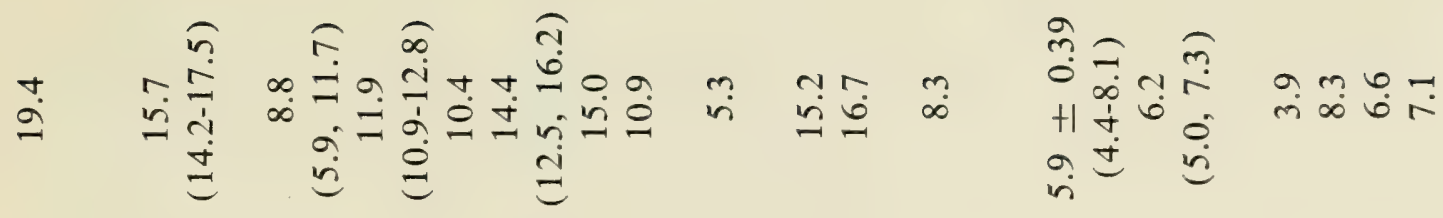

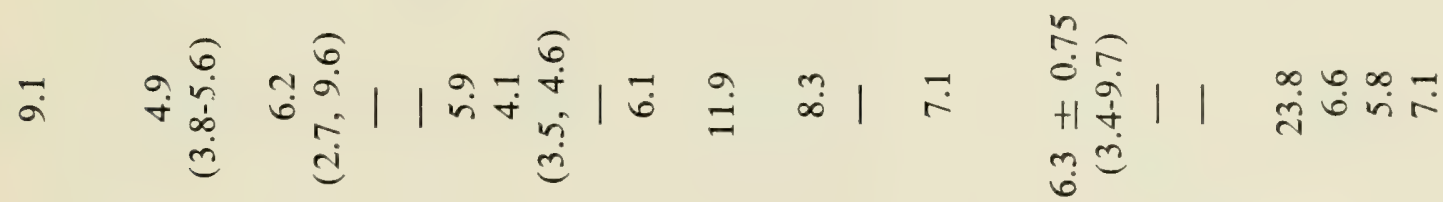

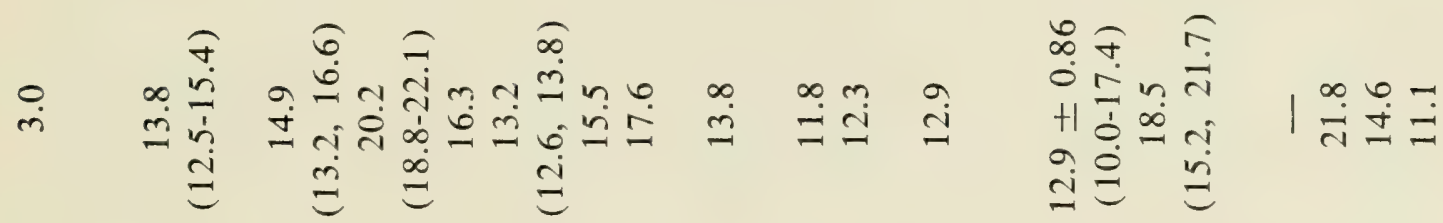

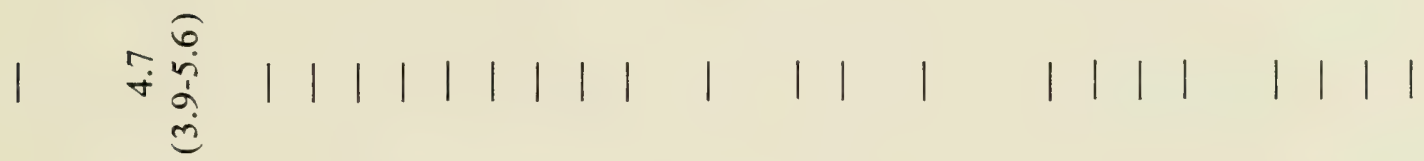

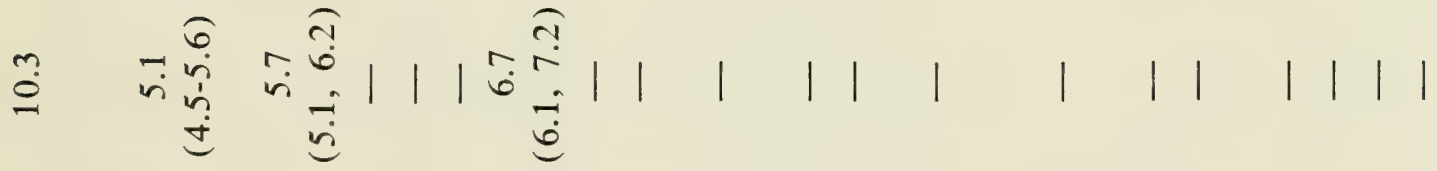

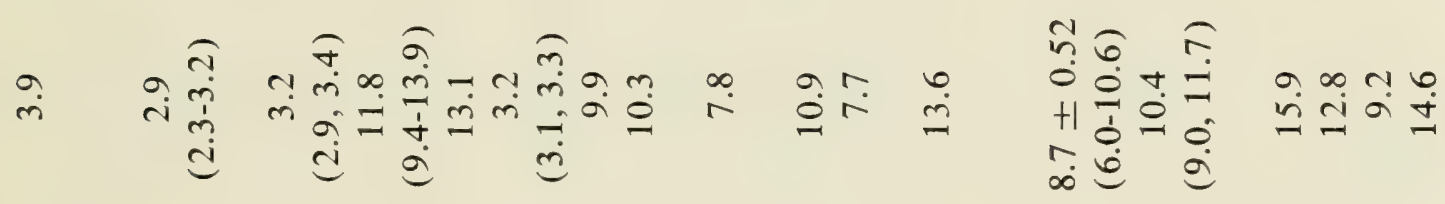

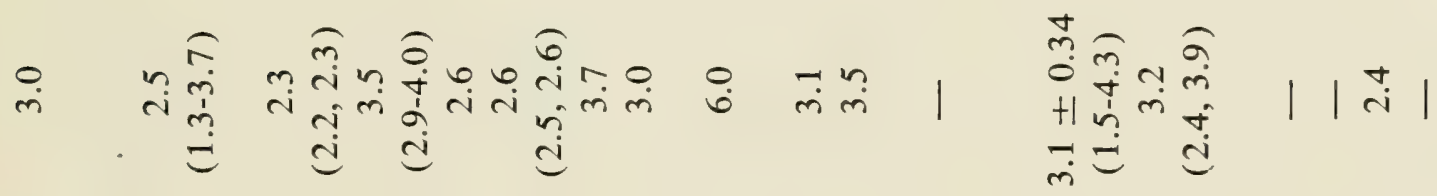

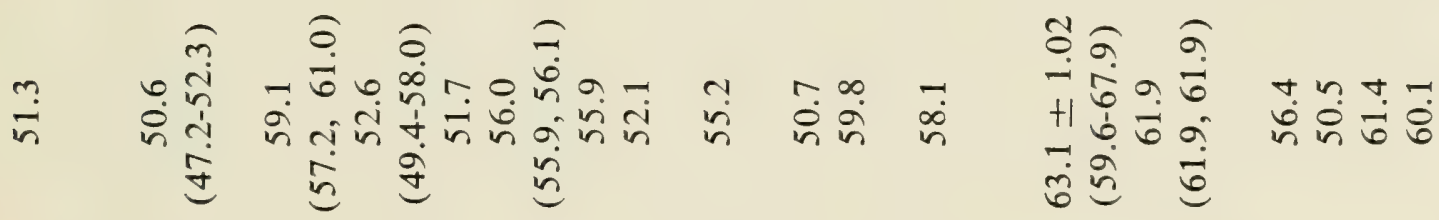

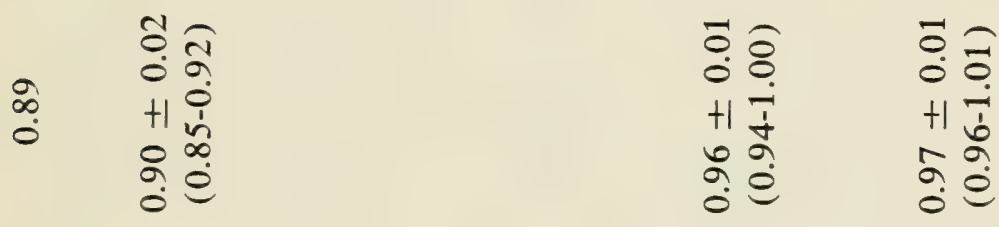

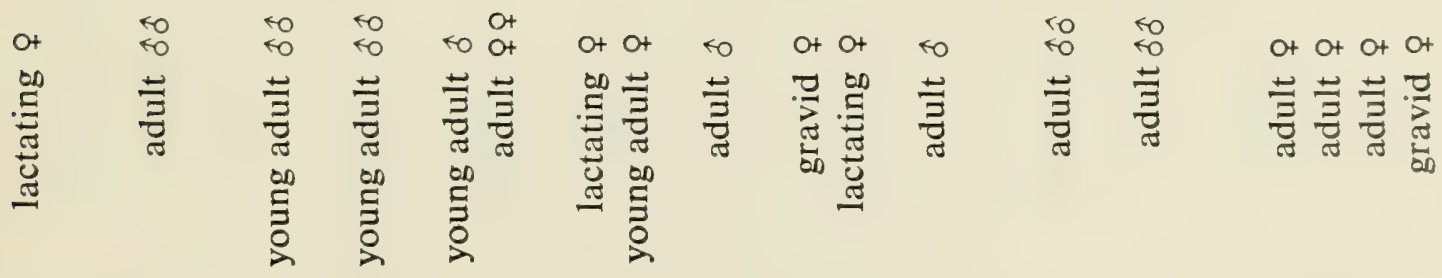

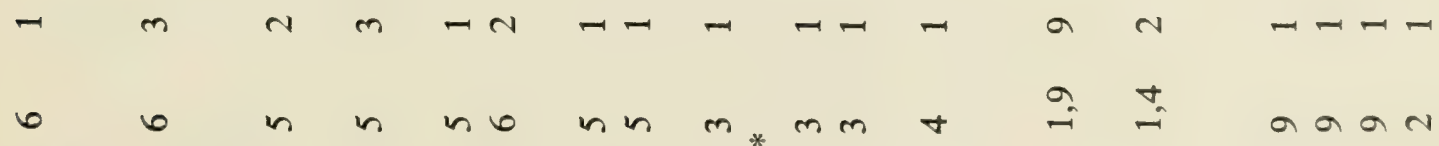
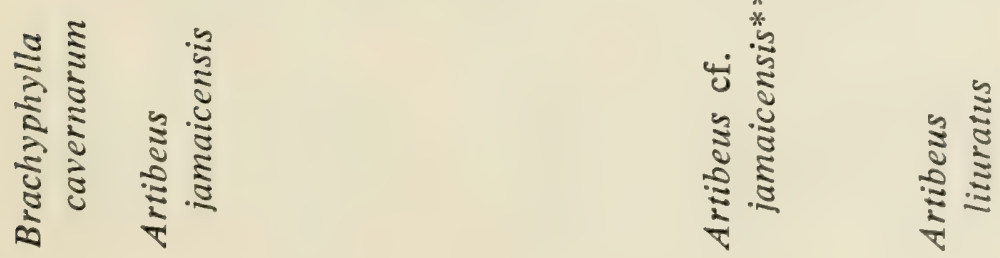


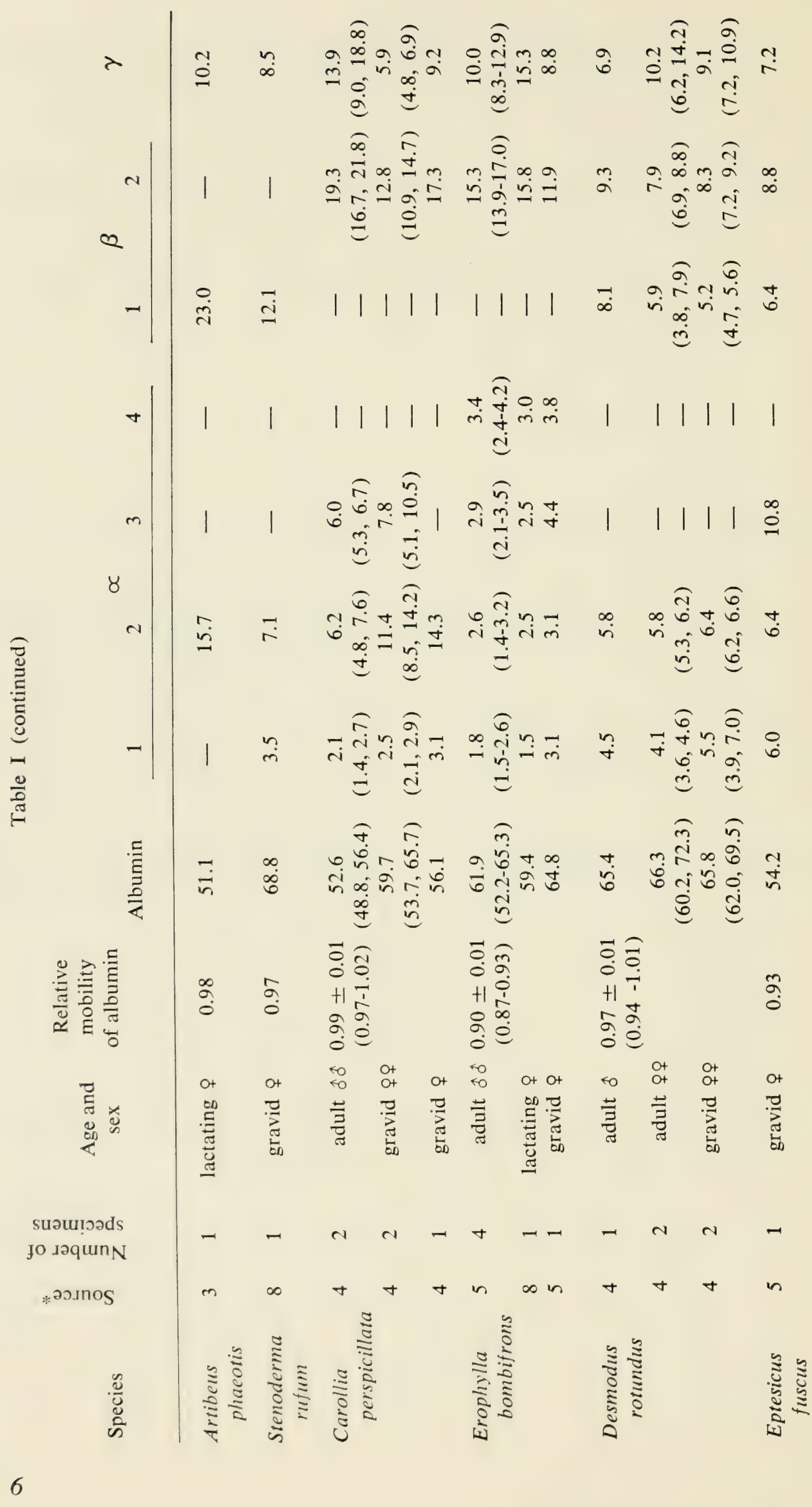




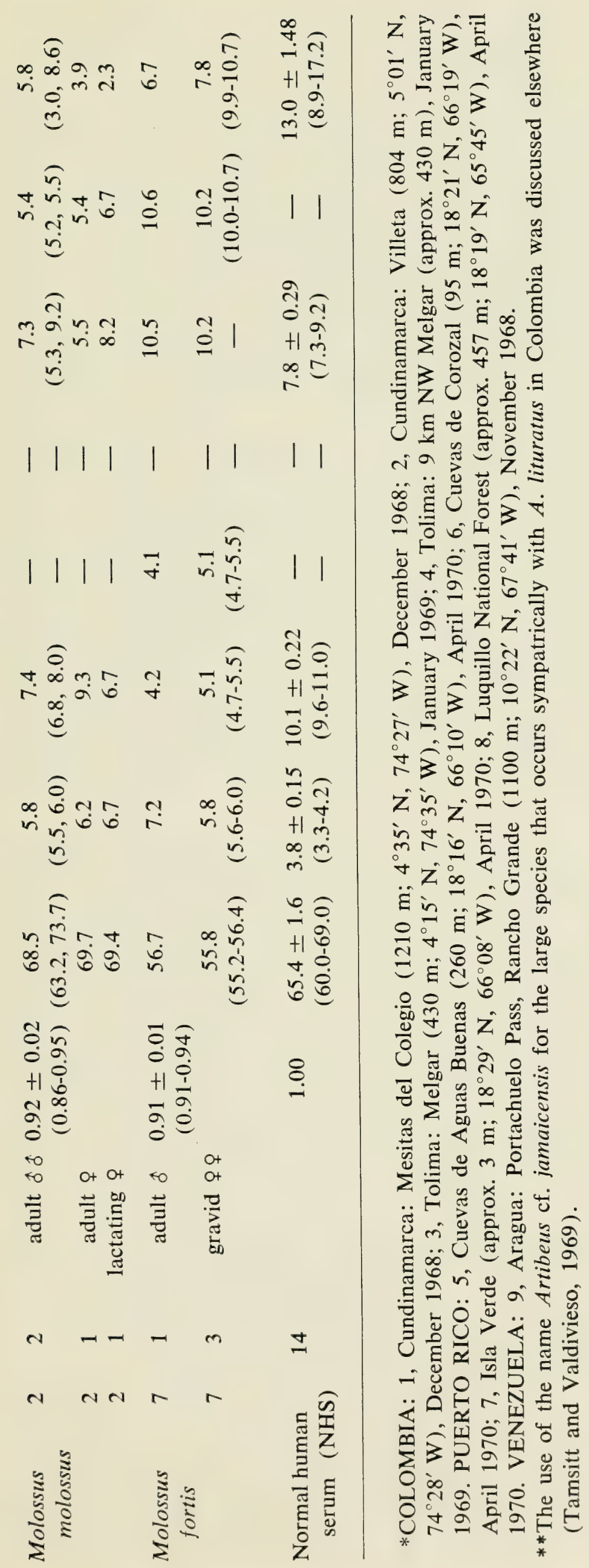




\section{Results}

\section{ELECTROPHEROGRAMS OF SERA}

Four to eight fractions were visible in electrophoretic patterns of chiropteran serum proteins (Figs. 1 and 2), and patterns of 18 species are summarized in Fig. 3. Quantitative aspects of profiles are compared in Table I. When polymorphism occurred, it involved fractions in the alpha and beta globulins. Interspecific differences were observed in the total number of fractions and in their relative mobilities (Fig. 3). Although varying in electrophoretic mobility among species, albumin, the most intense and rapidly migrating zone, and the gamma globulin fraction were monomorphic; consequently, although included in the total number of fractions, they are not discussed here.

Intraspecific variation in the number of fractions in the alpha and beta globulin regions occurred in seven species (Table I; Fig. 3). In Phyllostomus hastatus (Pallas) sera separated into five or six fractions (Fig. 1B,C). In the alpha region two fractions were present in a male and a female, whereas in another male and female three fractions were present. Five fractions, including two in the alpha and one in the beta region, were seen in adult $P$. discolor (Wagner). Serum of a male fetus, however, showed four fractions, with only one in the alpha region (Fig. 1D). Four or five fractions were present in Glossophaga soricina (Pallas). An adult, nonparous female possessed a single alpha globulin and a single beta globulin, whereas in a gravid female an additional alpha fraction was present (Fig. 1C).

In Artibeus jamaicensis Leach serum protein fractions varied from five to eight (Figs. 1A,E; 2A). Adult males had the greatest number (eight), with four fractions in the alpha region and two in the beta globulin region. In two adult females fractions numbered seven (three alpha and two beta). A lactating female had only five fractions, with two alphas and a single beta, a pattern similar to that of three young adult males in which the third and fourth alpha fractions were absent. Of the age groups, young adult males were the most variable; two had seven fractions (three alpha and two beta), one had six (two alpha and two beta), and three had five (two alpha and one beta fractions). One young adult female had six fractions, two alpha and two beta globulins that were comparable to those of one of the young adult males.

Five or six fractions were found in sera of Artibeus cf. jamaicensis (Fig. 2 B). Six fractions were found in an adult male and a gravid female, with two in the alpha region and two in the beta region. Only five fractions were seen in a lactating female, whose electropherogram was identical to that of other adults except for the absence of one of the beta globulins.

Serum fractions of Artibeus lituratus Olfers from Colombia and Venezuela varied in number from four to six (Figs. 1C; 2B,C). Adult males possessed five or six fractions; those with five fractions had either two fractions in the alpha region and one in the beta region (one male from Colombia, one male from Venezuela) or one fraction in the alpha region 
and two fractions in the beta region (one male from Colombia). Males with six fractions possessed two in the alpha and two in the beta regions (four males from Colombia, five from Venezuela). Serum fractions in females varied from four to six. One adult female (Venezuela) had only four fractions, including a single alpha and a single beta globulin. One adult, non-parous female (Venezuela) had six fractions, with two in the alpha and two in the beta regions. One gravid female (Colombia) and one adult, non-parous female (Venezuela) possessed five fractions, including one in the alpha and two in the beta regions. Samples from Colombia and Venezuela showed the same degree of variability, and numbers of serum fractions varied in individuals of each of the disjunct populations.

In Carollia perspicillata Linnaeus five or six serum fractions were present (Fig. 1C,F). Patterns in two males and two gravid females were identical, consisting of three fractions in the alpha and one in the beta region. In one gravid female, however, only two fractions were present in the alpha region.

Comparison of percentage composition of serum proteins by fraction according to sex and age without specific allocation resulted in only one statistically significant difference. The percentage (13.8) of fractions in the alpha region was significantly less in 14 adult, non-parous females than that (29.8) in 13 gravid females $(P \leq 0.025)$, although no other differences were found. Nor were significant differences $(P<0.05)$ found between adult and young adult males, between adult males and adult females, between adult and lactating females, or between adult and young adult females.

\section{RELATIVE MOBILITY OF ALBUMIN}

Among the species studied, none of the albumins migrated anodal to the NHS control (Table I; Figs. 1-3). Artibeus cf. jamaicensis, A. lituratus, A. phaeotis (Miller), Stenoderma rufum St. Hilaire, Carollia perspicillata, and Desmodus rotundus (Geoffroy) possessed albumins that had the same mobility as the NHS control. Glossophaga soricina, Monophyllus redmani Leach, Sturnira lilium (Geoffroy), Brachphylla cavernarum Gray, Artibeus jamaicensis, Erophylla bombifrons (Miller) (Phyllostomatidae), Eptesicus fuscus Palisot de Beauvois (Vespertilionidae), Molossus molossus (Pallas), and M. fortis Miller (Molossidae) possessed albumins with similar mobilities that were cathodic to the NHS control. Phyllostomus discolor and $P$. hastatus possessed albumin mobilities that differed from other species by being the most cathodic (Fig. 3). Likewise, the mobility of the albumin of $P$. discolor was more cathodic than that of $P$. hastatus. The mobility of the albumin of Pteronotus parnellii (Gray) (Mormoopidae) was slightly cathodic to albumins of the species of Phyllostomus studied.

\section{PROTEIN CONCENTRATION}

Values of total protein content $(\mathrm{g} / 100 \mathrm{ml})$ of sera of adult bats ranged from 4.08 in Monophyllus redmani to 6.55 in Phyllostomus discolor and Artibeus jamaicensis, but most values were between 5 and 6 (Table II). 


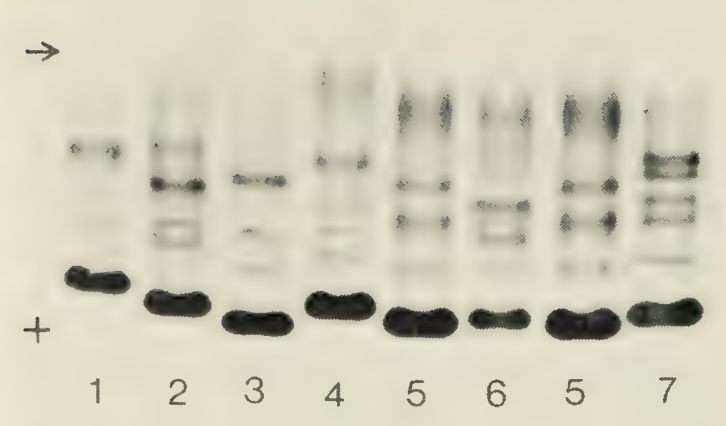

A

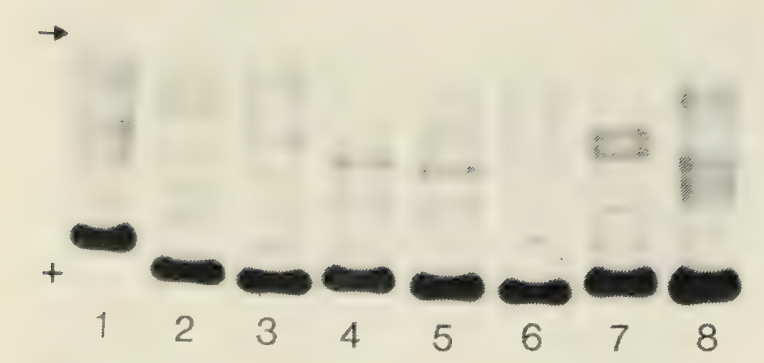

C

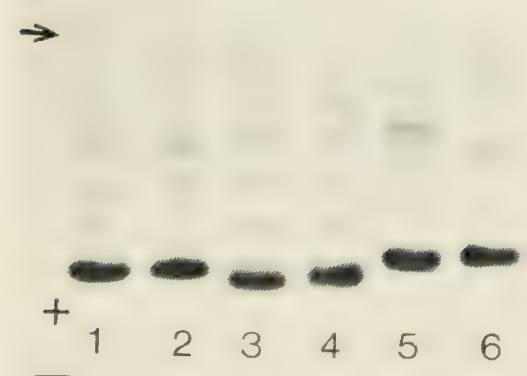

E

Fig. 1 Electrophoretic patterns of serum proteins of bats. The arrow indicates the point of application.

A. 1, Pteronotus parnellii 8 ; 2, Artibeus jamaicensis $\$$; 3, Stenoderma rufum \&; 4, Erophylla bombifrons ; ; 5, 7, normal human serum (NHS); 6, Eptesicus fuscus + ; 8, Molossus fortis 9 . All from Puerto Rico.

B. Phyllostomus hastatus (Venezuela): 1, 6, NHS; 2, 3, 우; 4, 5, 8 of.

c. 1, Phyllostomus hastatus $q$ (Venezuela); 2, Glossophaga soricina $q$ (Colombia); 3, Carollia perspicillata ô (Colombia); 4, Sturnira lilium ô (Colombia); 5, Artibeus lituratus of (Colombia); 6, Desmodus rotundus $q$ (Colombia); 7, Molossus molossus ô (Colombia); 8, NHS.

D. Phyllostomus discolor (Colombia): 1, 6, NHS; 2, fetus $6 ; 3$, young adult $\hat{\delta} ; 4, \delta ; 5$, ᄋ. 
Differences in our samples unequivocally attributable to age were negligible except in $P$. discolor, in which values for an adult were greater than those of a fetus. Differences in protein concentration in young adult and adult $A$. jamaicensis were insignificant $(P \geq 0.05)$, as were these values for adult males and females.

The relative proportions of protein $(\mathrm{g} \%)$ of the serum fractions were variable and apparently influenced to some extent by age or reproductive condition. Adult and young adult $A$. jamaicensis did not differ significantly $(0.10<P>0.05)$ in percentages of beta and gamma globulins, nor did other protein fractions differ significantly between age groups or between sexes. In $\boldsymbol{P}$. discolor differences between the adult and fetus were primarily in the reduced percentages of albumin and alpha fractions of the latter, although per cent protein of the gamma of adult and fetus were comparable. Young adult and adult $A$. jamaicensis were only near-significantly different $(P \leq 0.05)$ in per cent protein of the gamma fraction. The greatest percentage of protein in the gamma region was found in a lactating Brachyphylla cavernarum and the least in a young adult male $A$. jamaicensis, an adult male Desmodus rotundus, and an adult male Molossus fortis (Table II). Percentages of protein in the alpha and beta fractions varied remarkably and could not be correlated with age, sex, or taxon.

\section{Discussion}

Species similarities established by serum protein electropherograms (Fig. 3 ) do not agree with existing taxonomic arrangements. Bats of the family Phyllostomatidae have a particularly wide range of variation in serum protein patterns similar to that reported for karyotypes by Baker (1970).

Although no albumin polymorphism was observed in populations of species studied, differences and similarities were noted among several groups of species (Table I; Fig. 3). None of the albumins studied migrated anodically to the NHS control; in all species albumin had the same mobility as the control or was cathodic to it. According to mobility of albumin, four groups could be distinguished: (1) Pteronotus parnellii (Mormoopidae); (2) the Phyllostomatinae represented by Phyllostomus hastatus and $P$. discolor, which, although differing in mobilities, had the most cathodic albumins of the bats studied; (3) a group of phyllostomatid bats whose albumin mobilities were identical with NHS albumin: three species of Artibeus ( $A$. cf. jamaicensis, $A$. lituratus, and $A$. phaeotis), the single species of Stenoderma, one species of Carollia, and the vampire bat Desmodus rotundus; and (4) a larger group of bats representing three families whose albumins were slightly cathodic to that of the control and similar to that of $P$. parnellii: the glossophagine bats Glossophaga soricina and Monophyllus redmani, the stenodermine bats Sturnira lilium, A. jamaicen-

E. 1, 2, Artibeus jamaicensis (1, ; 2, ô); 3, NHS; 4, Molossus fortis ô ; 5, Monophyllus redmani ㅇ ; 6 , Brachyphylla cavernarum + . All from Puerto Rico.

F. Carollia perspicillata (Colombia): 1, NHS; 2-4, gravid $\uparrow \uparrow ; 5, \delta$. 


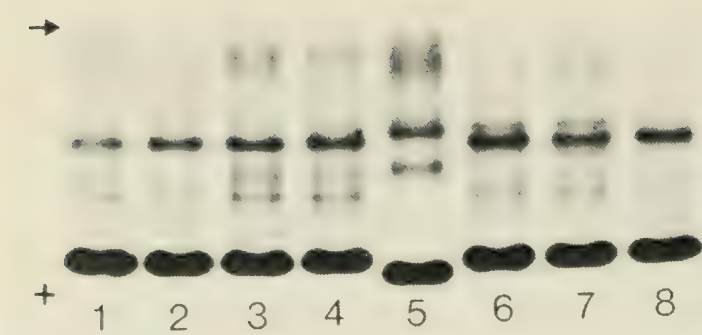

A
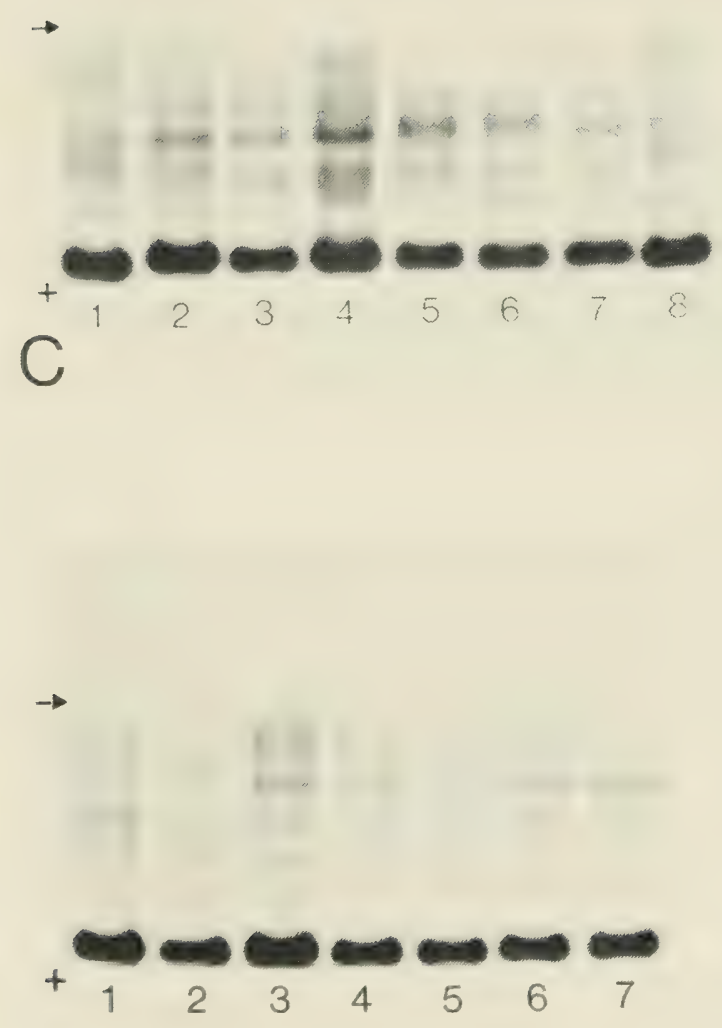

E

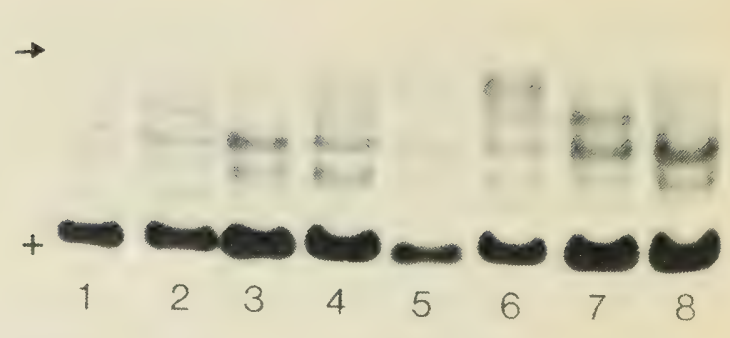

B
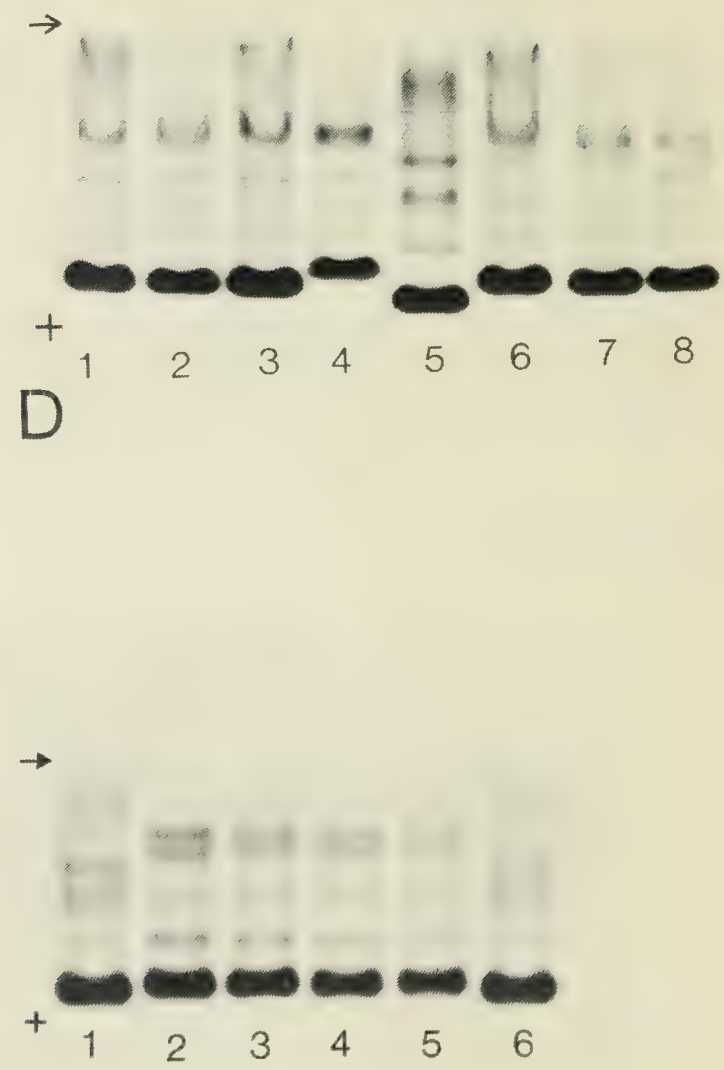

F

Fig. 2 Electrophoretic patterns of serum proteins of bats. The arrow indicates the point of application.

A. Artibeus jamaicensis (Puerto Rico): 1, 2, ㅇ \&; 3, 4, 6-8, ô ô; 5, normal human serum (NHS).

в. 1, NHS; 2, 3, Artibeus lituratus ô ô; 4, Artibeus lituratus gravid $q ; 5$, 7, Artibeus cf. jamaicensis lactating क; 6, Artibens cf. jamaicensis gravid ㅇ; 8 , Artibeus phaeotis lactating ․ All from Colombia.

c. 1, 8, NHS; 2-4, Artibeus lituratus ô ô (Colombia); 5-7, A. lituratus tô ô (Venezuela).

D. 1, 5, NHS; 2, 3, 6-8, Erophylla bombifrons (2, ; 3, 6-8, ôे ô ); 4, Pteronotus parnellii î. All from Puerto Rico.

E. Desmodus rotundus (Colombia): 1, NHS; 2, 3, + \& 4, 5, gravid +9 ;

$6,7, \hat{\jmath}$.

F. Molossus molossus (Colombia): 1, 6, NHS; 2, 3, ô ô; 4, $q$; 5, lactating ㅇ. 
sis, and Brachyphylla cavernarum, the phyllonycterine bat Erophylla bombifrons (Phyllostomatidae), Eptesicus fuscus (Vespertilionidae), and Molossus molossus and M. fortis (Molossidae).

It is noteworthy that albumin mobilities of the two congeneric species Phyllostomus hastatus and $P$. discolor were significantly different $(0.005$ $\langle P\rangle$ 0.001). Likewise, although mobilities of albumin of the three species of mainland Artibeus were similar or not significantly different $(P>0.05)$, mobilities of albumin of $A$. jamaicensis from Puerto Rico and of mainland $A$. lituratus and $A$. cf. jamaicensis differed significantly (0.01 $<P>0.025$ ).

The status of bats previously placed in the subfamily Chilonycterinae has been questioned (Koopman and Jones, 1970; Jones and Genoways, 1970), and species of the genera Pteronotus and Mormoops were recently placed by Smith (1972) in a distinct family, the Mormoopidae. Although $P$. parnellii was the only taxon of this family we studied, the mobility of the albumin of this species from Puerto Rico was intermediate between the phyllostomatid bats of the subfamily Phyllostomatinae ( $P$. hastatus and $P$. discolor) on the one hand and the phyllostomatid bats of the subfamilies Stenoderminae ( $G$. soricina, $M$. redmani, S. lilium, B. cavernarum, A. jamaicensis) and Phyllonycterinae (E. bombifrons), and of the families Vespertilionidae ( $E$. fuscus) and Molossidae ( $M$. molossus and $M$. fortis) on the other. G. soricina, M. redmani, and $S$. lilium have fewer globulin fractions than $P$. parnellii, whereas $B$. cavernarum and $A$. jamaicensis have a greater number. Hemoglobins (Valdivieso et al., 1969) and immunologic properties of serum proteins (Gerber and Leone, 1971) of species of Pteronotus differ from those of bats of the Phyllostomatidae. But the serum protein pattern of $P$. parnellii does not differ markedly from other bats studied and consequently does not support the contention of Smith (1972) that this group represents a distinct family.

The two species of the subfamily Phyllostomatinae, Phyllostomus hastatus and $P$. discolor, have the most cathodic albumin of all bats studied and differ from other taxa in the Phyllostomatidae in this character. In numbers and mobilities of protein fractions, $P$. hastatus is more similar to Pteronotus parnellii of the Mormoopidae than to either $P$. discolor of the same genus or to other taxa of the Phyllostomatidae. Adult $P$. discolor have one less fraction than $P$. hastatus and are unique among the bats studied. These two species differ in a number of morphological characters and food habits (Walker, 1968) and as well differ in susceptibility to dental disease (Phillips and Jones, 1970) and in thermoregulatory abilities (McNab, 1969). Likewise, although chromosomes of the two taxa are similar, they differ in one pair of autosomes, an exception to the undifferentiated karyotypes typically encountered among different species of the same genus (Kiblisky, 1969). Electrophoretic patterns of hemoglobins, however, do not differ between the two species or among bats of other subfamilies of the Phyllostomatidae (Tamsitt and Valdivieso, 1969).

Sturnira lilium, in albumin mobility, does not differ from Brachyphylla cavernarum, Artibeus jamaicensis, Monophyllus redmani, and Erophylla 


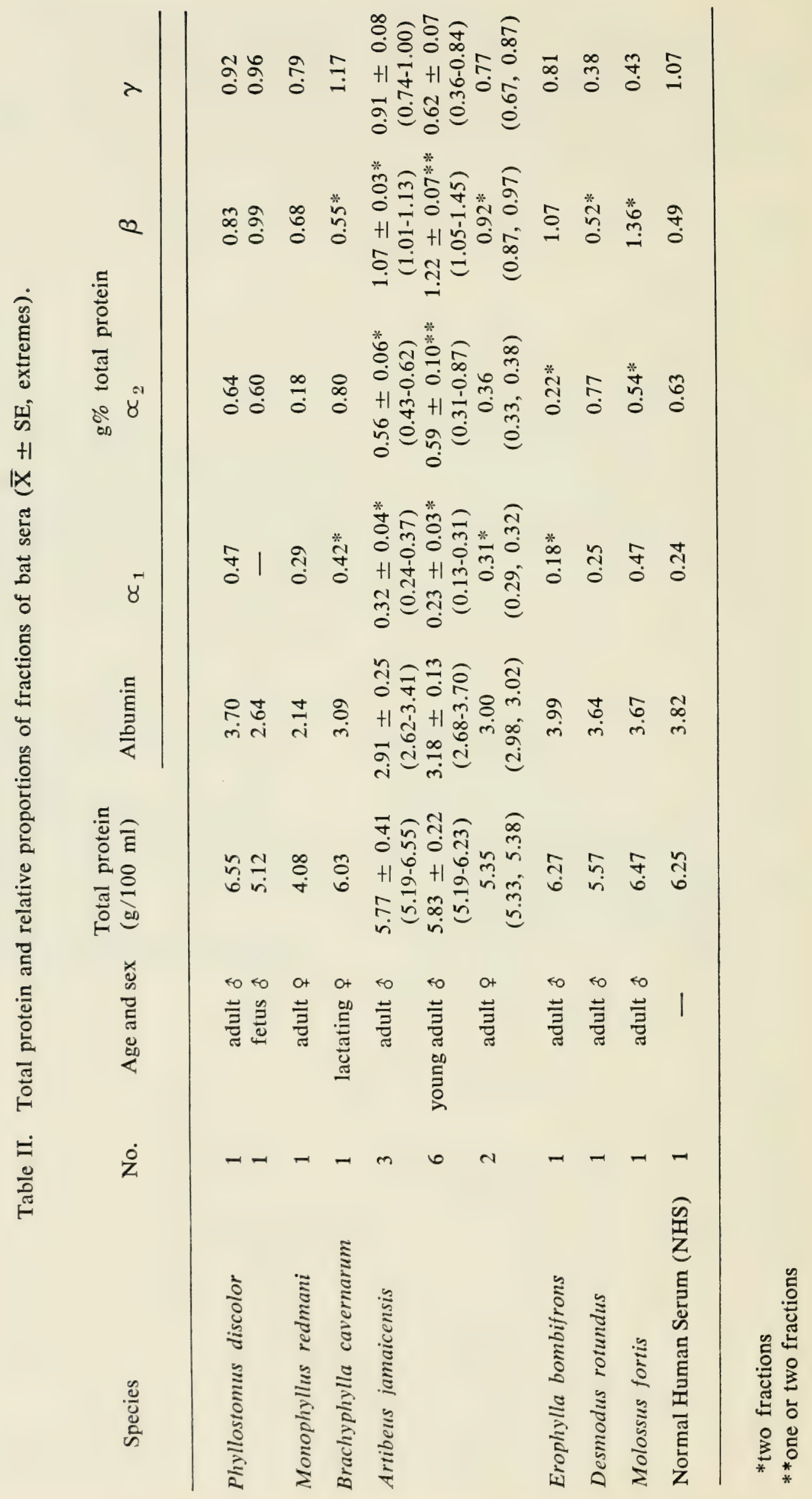


bombifrons. In the number of fractions in the globulin regions, however, S. lilium is more similar to Stenoderma rufum and Monophyllus redmani than to other phyllostomatid bats. Although once considered to be a separate subfamily, the Sturnirinae (Miller, 1907), Koopman and Jones (1970) placed bats of the genus Sturnira in the Sternoderminae but in a separate tribe, the Sturnirini. In karyotypes (Gardner and O'Neill, 1969), electrophoretic properties of hemoglobins (Tamsitt and Valdivieso, 1969), and immunological properties of sera (Gerber and Leone, 1971), species of Sturnira have strong affinities with bats of the subfamily Stenoderminae. The serum protein pattern of $S$. lilium closely resembles that of Carollia perspicillata (Fig. 3), differing primarily in albumin mobility. Our data thus indicate a relationship with the carolline and glossophagine bats as well as with stenodermine bats.

Species of the genus Brachyphylla were recently placed as a tribe of the subfamily Stenoderminae (Phyllostomatidae) by Koopman and Jones (1970) but as a member of the Phyllonycterinae by Silva and Pine (1969). In albumin mobility $B$. cavernarum is similar to phyllostomatids from mainland South America ( $G$. soricina and $S$. lilium) and from Puerto Rico (M. redmani, A. jamaicensis, and E. bombifrons). In globulin fractions, however, $B$. cavernarum differs primarily from the above in number and position except in those individuals of $A$. jamaicensis that possess six fractions. Although species of the genera Erophylla and Brachyphylla are similar in morphology and behaviour (Silva and Pine, 1969), karyotypes (Baker and Lopez, 1970), hair structure (Benedict, 1957), and possess in common host-specific spinturnicid mites (Dusbábek, 1969), the serum protein pattern of $B$. cavernarum is surprisingly unlike that of $E$. bombifrons and more similar to that of the vespertilionid bat Eptesicus fuscus.

Erophylla bombifrons differs from other phyllostomatids studied in the same way that $B$. cavernarum differs. These two species are similar in albumin mobility but differ in mobilities and numbers of globulin fractions. Lactate dehydrogenase isoenzymes of $B$. bombifrons differ from those of Puerto Rican $A$. jamaicensis (Valdivieso et al., 1968), and although species of Erophylla unquestionably are taxonomically distinct from stenodermine bats, results from electrophoretic studies of serum proteins do not confirm the conclusion of Silva and Pine (1969).

Of the four species of Artibeus, the insular A. jamaicensis differs from the mainland $A$. lituratus, $A$. cf. jamaicensis, and $A$. phaeotis by having a slower-moving albumin and by a greater number of protein fractions (eight as opposed to 4-6). A. lituratus and $A$. cf. jamaicensis are similar in mobilities of protein fractions, but although the slower fraction in the beta region may or may not be present in individuals of both species, only in $A$. cf. jamaicensis is the fastest fraction in the alpha region always present. $A$. phaeotis, although having the same albumin mobility as $A$. lituratus and $A$. cf. jamaicensis, differs from these two taxa by the absence of the dimorphic, slower beta fraction and by the absence of the faster fraction in the alpha region. 


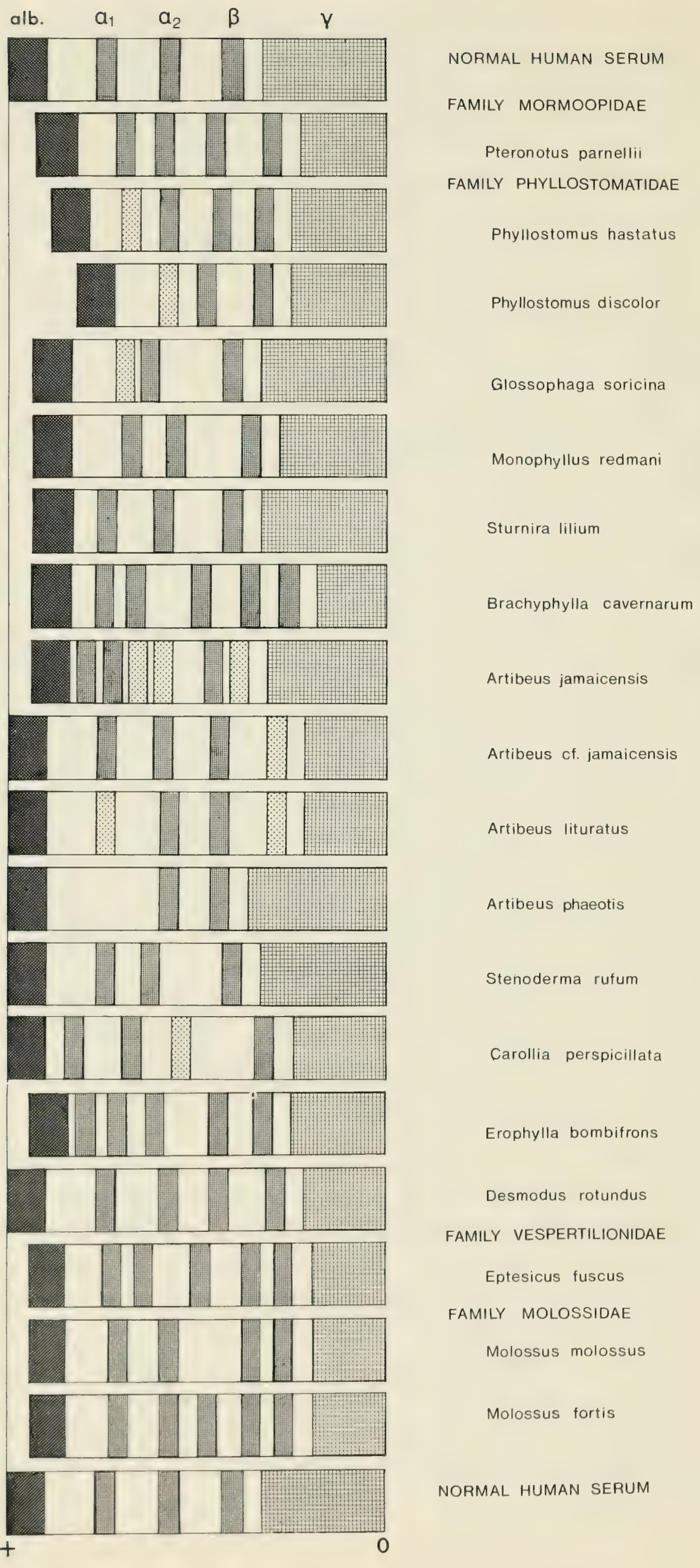


Comparison among these congeneric species presents striking differences that raise questions of functional necessity and diversity of serum proteins. In $A$. phaeotis, the limited number of fractions contrasts with the marked complexities of fractions of sera in all individuals of $A$. lituratus and $A$. jamaicensis. In many respects species of Artibeus are obviously diverse, e.g., A. phaeotis has higher immunological affinities with other phyllostomatid bats than with the related $A$. jamaicensis (Gerber and Leone, 1971) and moreover differs chromosomally from other species of Artibeus (Genoways and Baker, 1972). On the other hand, hemoglobins of all Artibeus species studied here are electrophoretically indistinguishable from each other and from other phyllostomatid bats (Valdivieso et al., 1969; Tamsitt and Valdivieso, 1969).

Stenoderma rufum, one of the least known neotropical stenodermine bats (Jones et al., 1971), is similar to mainland South American phyllostomatids (Carollia, Artibeus, and Desmodus) but differs from other Puerto Rican phyllostomatid bats (A. jamaicensis, B. cavernarum, M. redmani, and $E$. bombifrons) in albumin mobility. In number and mobilities of globulin fractions, $S$. rufum differs from all phyllostomatids studied and is more similar to the glossophagine bats $M$. redmani and $G$. soricina. Chromosomally, however, S. rufum is similar to Artibeus species (Baker and Lopez, 1970; Genoways and Baker, 1972) and moreover shares a species of listrophorid mite in common with Puerto Rican $A$. jamaicensis (Cruz et al., 1974). The electrophoretic pattern of hemoglobin of $S$. rufum is indistinguishable from Puerto Rican or mainland phyllostomatids (Valdivieso et al., 1969; Tamsitt and Valdivieso, 1969). Why the serum protein fractions of $S$. rufum are more similar to glossophagine bats, both insular and mainland, than to phylogenetically-related stenodermine bats remains to be determined.

The genus Carollia, placed in the subfamily Carollinae of the Phyllostomatidae (Koopman and Jones, 1970), is similar to mainland Artibeus species, $S$. rufum, and $D$. rotundus in albumin mobility but differs from these taxa in number and mobilities of fractions in the globulin regions. Although electrophoretic properties of hemoglobins of $C$. perspicillata do not differ from other phyllostomatid bats (Tamsitt and Valdivieso, 1969), immunologically species of Glossophaga (Glossophaginae) and Carollia are more closely related than has been inferred from morphological evidence (Gerber and Leone, 1971). Consequently, the taxonomic status of the Glossophaginae and Carollinae warrants further study.

Glossophaga soricina from South America and Monophyllus redmani from Puerto Rico (Glossophaginae) are similar in albumin mobilities but differ in number and mobilities of globulin fractions. Although similarities in chromosomes between species of Glossophaga and Phyllostomus were reported by Baker (1970), electropherograms of these taxa are strikingly different (Fig. 3).

Fig. 3 Schematic diagram of patterns of serum proteins of neotropical bats (cellulose polyacetate). The pattern of normal human serum is given as a reference. Fractions always present in the alpha and beta globulin regions are indicated by dark stippling; fractions that may be absent are represented by light stippling. O marks the origin; anode at left. Mobility of human albumin is indicated by a thin vertical line. 
Desmodus rotundus is similar to $S$. rufum, $C$. perspicillata, and all species of Artibeus examined except the insular $A$. jamaicensis in albumin mobility. The pattern of the serum electropherogram of $D$. rotundus is indistinguishable from those individuals of $A$. lituratus that exhibit a complete set of five globulin fractions and all but indistinguishable from those $A$. cf. jamaicensis possessing the same number of globulin fractions. Although once considered to be a distinct family, Desmodontidae (Anderson and Jones, 1967), vampire bats are now considered to be a subfamily of the Phyllostomatidae (Koopman and Jones, 1970). Immunological results (Gerber and Leone, 1971), karyotypic information (Forman et al., 1968), and data from electrophoretic analyses of hemoglobin (Tamsitt and Valdivieso, 1969), as well as data presented here on serum proteins, support this taxonomic allocation.

Of the molossids, insular Molossus fortis is similar to mainland $M$. molossus in albumin mobility, but the former differs from the latter by a larger number of fractions in the globulin regions. Although the molossid bats and the vespertilionid bat Eptesicus fuscus are similar to certain phyllostomatid bats in albumin mobility, these species differ from all phyllostomatid bats studied to date in electrophoretic properties of hemoglobin (Tamsitt and Valdivieso, 1969) and lactate dehydrogenases (Valdivieso et al., 1968). E. fuscus (Vespertilionidae) is similar to Molossus species in albumin mobility and in mobility of the two fractions in the beta region but differs by mobilities of the fractions in the alpha region.

Data on serum protein concentrations (total protein) have been published on hedgehogs (Morris and Rudge, 1970), deer (Seal and Erickson, 1969), and other mammals, primarily domestic (Schalm, 1970). A wide range $(6-11 \mathrm{~g} / 100 \mathrm{ml})$ has been reported in total protein of mammals, and concentrations reported here $(4.1-6.5 \mathrm{~g} / 100 \mathrm{ml})$ for bats are toward the lower extreme of values (Table II). Although differences among reports may result from analytical procedures, as most methods are influenced by variations in technique (King, 1964), reasons for reduced concentrations of protein in bat sera remain unexplained.

The sera or plasma of many different mammals including rodents (Nadler, 1968; Dalby and Lillevik, 1969), artiodactyls (Nadler et al., 1967; Seal and Erickson, 1969), and cetaceans (Gallien et al., 1970) have been studied electrophoretically, and data have been applied to the systematics of groups at various levels of the taxonomic hierarchy. In some groups serum protein patterns are useful to distinguish species (van Tets and McT. Cowan, 1966; Petersen, 1968; and others), whereas in others they are phylogenetically conservative (Gallien et al., 1970). Certain fractions of sera have been demonstrated to be polymorphic within a species, particularly albumins, transferrins, haptoglobins, and other post-albumins (see Manwell and Baker, 1970). Few data, however, are available to compare the amount of protein variation in tropical and temperate species; moreover, except for immunologic analyses of some phyllostomatids (Forman et al., 1968; Gerber and Leone, 1971), no data exist on serum proteins of tropical bats except those presented here. 
Bats are a suitable group for studies in biochemical systematics, for much of their taxonomy has been well defined by morphological characters. There are nonetheless many interesting taxonomic problems in neotropical Chiroptera, and the recent application of criteria from biochemistry, serology, and particularly karyology (see Baker, 1970) have helped elucidate evolutionary relationships not revealed by conventional morphological characters. The Desmodontinae (vampire bats), once regarded as a distinct family, is now recognized as a subfamily of the Phyllostomatidae (Koopman and Jones, 1970); evidence from karyotypes (Hsu and Bernirshke, 1967) and immunologic analyses (Forman et al., 1968) was instrumental in determining this affinity. Bats of the genus Sturnira, previously considered a separate subfamily (Sturnirinae) of the Phyllostomatidae, were placed in the subfamily Stenoderminae (Koopman and Jones, 1970), an allocation supported by similarities of chromosomes (Gardiner and O'Neill, 1969), hemoglobins (Tamsitt and Valdivieso, 1969), and data presented here on serum proteins.

Speculation or correlation between electrophoretic patterns and developmental processes has been intentionally avoided until the separated proteins can be more fully characterized. But the normal electropherograms of certain species of neotropical bats have been established, and knowledge of such electrophoretic patterns may be useful in other studies. Likewise, cellulose polyacetate patterns of sera of bats may have taxonomic value, for specics can be differentiated, and relationships between certain taxa are indicated. Here, for example, we pointed out potential problems concerning relationships among the Phyllostomatidae and the relationship of species of Phyllostomus to other phyllostomatids. Variations in patterns of individuals and populations were considerable but may provide information for intraspecific studies. A thorough analysis of quantitative differences within a single species is needed, as are immunological data to determine homologies of serum fractions among taxa.

\section{Summary}

Serum proteins of 75 bats of 18 species of the families Mormoopidae, Phyllostomatidae, Vespertilionidae, and Molossidae from Colombia, Puerto Rico, and Venezuela were compared by cellulose polyacetate electrophoresis. Number of fractions varied from four to eight in electrophoretic patterns. Interspecific differences were observed in the total number of fractions and in their relative mobilities. Although varying in mobility among species, albumin, the most intense and rapidly migrating zone, and the fraction in the gamma globulin region were monomorphic in all species. Polymorphism occurred in the number of fractions in the alpha and beta regions of Phyllostomus hastatus, $P$. discolor, Glossophaga soricina, Artibeus jamaicensis, $A$. cf. jamaicensis, A. lituratus, and Carollia perspicillata (Phyllostomatidae).

Comparison of percentage composition of fractions of serum proteins by sex and age without specific allocations resulted in statistically insignificant differences, except that the percentage of fractions in the alpha glob- 
ulin region was significantly less in adult than in gravid females. Total protein content $(\mathrm{g} / 100 \mathrm{ml})$ varied from 4.1-6.5, and differences by species or attributable to sex or age were negligible except that values for an adult Phyllostomus discolor were greater than those of a fetus.

Based on similarities of albumin mobilities, four groups were evident: (A) Pteronotus parnellii (Mormoopidae); (B) the phyllostomatid bats Phyllostomus hastatus and $P$. discolor (Phyllostomatinae); (C) the phyllostomatid bats Glossophaga soricina and Monophyllus redmani (Glossophaginae), Sturnira lilium, Brachyphylla cavernarum, Artibeus jamaicensis (Stenoderminae), Erophylla bombifrons (Phyilonycterinae), the vespertilionid bat Eptesicus fuscus (Vespertilionidae), and the free-tailed bats Molossus molossus and M. fortis (Molossidae); and (D) the phyllostomatid bats Artibeus cf. jamaicensis, A. lituratus, A. phaeotis, Stenoderma rufum (Stenoderminae), Carollia perspicillata (Carollinae), and Desmodus rotundus (Desmodontinae).

\section{Resumen}

Se comparan las proteinas de sueros de 75 ejemplares correspondientes a 18 especies de quirópteros de las familias Mormoopidae, Phyllostomatidae, Vespertilionidae y Molossidae de Colombia, Puerto Rico y Venezuela por medio de electroforesis de poliacetato de celulosa. Cuatro a ocho fracciones son visibles en los electroferogramas de estos murciélagos. Similaridades y diferencias cuantitativas y cualitativas son bien aparentes. Diferencias interespecíficas se observan en el número total de fracciones, lo mismo que en sus mobilidades relativas.

Albúmina, la zona más intensa y rápida, varía en ciertas de las especies estudiadas siendo en todos los casos monomórfica así como lo es la fracción correspondiente a la región de la gama globulina.

Cuando se observa polimorfismo en las fracciones proteínicas del suero, éste occure únicamente en el número de bandas presentes en las regiones alfa y beta de Phyllostomus hastatus, P. discolor, Glossophaga soricina, Artibeus jamaicensis, $A$. cf. jamaicensis, $A$. lituratus y Carollia perspicillata (Phyllostomatidae).

Comparaciones en el porcentaje de la composición de las fracciones de estas proteinas por sexo o edad, sin tener en cuenta alocaciones específicas, demuestran solamente una diferencia estadística significante: el porcentaje de fracciones en la región alfa es inferior en hembras adultas que en aquéllas grávidas. La concentración total de proteinas $(\mathrm{g} / 100 \mathrm{ml})$ varía de 4.1 a 6.5 sin observarse diferencias referentes a especies, sexo o edades excepto por los valores obtenidos en un Phyllostomus discolor adulto en el cúal son mayores que aquéllos correspondientes a un feto de la misma especie.

Basándonos en similaridades de mobilidad de albúminas podemos distinguir cuatro grupos diferentes: (A) Pteronotus parnellii (Mormoopidae); (B) los murciélagos filostomátidos Phyllostomus hastatus y $P$. discolor (Phyllostomatinae); (C) los filostomátidos Glossophaga soricina y Monophyllus redmani (Glossophaginae), Sturnira lilium, Brachyphylla cavernarum, Artibeus jamaicensis (Stenoderminae), Erophylla bombifrons 
(Phylloncyterinae), el vespertiliónido Eptesicus fuscus (Vespertilionidae) y los molósidos Molossus molossus y M. fortis (Molossidae); y (D) los filostomátidos A. cf. jamaicensis, A. lituratus, A. phaeotis, Stenoderma rufum (Stenoderminae), Carollia perspicillata (Carollinae) y el vampiro Desmodus rotundus (Desmodontinae).

Las propiedades electroforéticas de las proteinas del suero son taxonómicamente importantes pero pueden representar un valor limitado como indicadores de relaciones filogenéticas en estos mamíferos.

\section{Acknowledgments}

We are grateful to Dr. Omar Linares for field assistance; to the personnel of the Instituto de Zoología Tropical, Universidad Central, Caracas, for the use of laboratory facilities; to Dr. Gonzalo Medina Padilla, Director, Rancho Grande Biological Station, Venezuela, for his cooperation and for the use of facilities; and to the staff of the Department of Mammalogy, Royal Ontario Museum, for their assistance. We thank Dr. R. L. Peterson for aid in identification of specimens and for critically reading the manuscript. The illustrations were prepared by Mrs. Sophie Poray and Mr. Leighton R. Warren, Royal Ontario Museum. Our research was supported by the National Research Council of Canada, the Canadian National Sportsmen's Show, the Penrose Fund of the American Philosophical Society, the Ontario Department of University Affairs, and the Royal Ontario Museum. 


\section{Literature Cited}

ANDERSON, S. AND J. K. JONES, JR., eds.

1967 Recent mammals of the world; a synopsis of families. New York, Ronald Press. 453 pp.

BAKER, R. J.

1970 The role of karyotypes in phylogenetic studies of bats. In Slaughter, B. H. and D. W. Walton, eds. About bats; a chiropteran biology symposium. Dallas, Southern Methodist University Press, pp. 303-312.

BAKER, R. J. AND G. LOPEZ

1970 Karyotypic studies of the insular populations of bats of Puerto Rico. Caryologia 23(4): 465-472.

BECKMAN INSTRUMENT CO.

1962 Total protein; total, albumin, albumin/globulin ratio: ultramicro adaptation of the method of (1) Kingsley (2) Gornall, Bradawill and David. Tech. Bull. 6074D. 2 pp.

1967 Model R-110 microzone densitometer; instruction manual. Palo Alto, Calif. 48 pp.

BENEDICT, F. A

1957 Hair structure as a generic character in bats. Univ. Calif. Publs. Zool. $59(8): 285-548$

COATES, $M$.

1967 A comparative study of the serum proteins of the species of Taricha and their hybrids. Evolution, Lancaster, Pa. 21(1): 130-140.

CRUZ, J. DE LA, J. R. TAMSITT AND D. VALDIVIESO

1974 Three new species of labidocarpine mites (Listrophoroidea, Chirodiscidae) from Puerto Rican bats. Life Sci. Occ. Pap., R. Ont. Mus. 23: 1-16.

DALBY, P. L. AND H. A. LILLEVIK

1969 Taxonomic analysis of electrophoretic blood serum patterns in the cotton rat, Sigmodon. Publs. Mich. St. Univ. Mus. 4(3): 67-101.

DESSAUER, H. C. AND W. FOX

1964 Electrophoresis in taxonomic studies illustrated by analyses of blood proteins. In Leone, C. A., ed. Taxonomic biochemistry and serology. New York, Ronald Press, pp. 625-647.

DUSBÁBEK, F.

1969 To the phylogeny and zoogeography of bats (Chiroptera) based on the study of their parasitic mites (Acarina). Lynx (Praha) n. s., 10: 19-24.

FEENEY, R. E AND R. G. ALLISON

1969 Blood plasma proteins. In Feeney, R. E. and R. G. Allison, eds. Evolutionary biochemistry of proteins. New York, Wiley-Interscience, pp. 117-143.

FORMAN, G. L., R. J. BAKER AND J. D. GERBER

1968 Comments on the systematic status of vampire bats (family Desmondontidae). Syst. Zool. 17(4): 417-425.

GALlien, C. L., M. TH. CHALUMEAU-LE-FOUlgoC AND J. M. FINE

1970 Comparative study of serum proteins in four dolphin species (Cetaces [sic]-Odontocetes). Comp. Biochem. Physiol. 37(3): 375-385.

GARDINER, L. AND P. O'NEILL

1969 The taxonomic status of Sturnira bidens (Chiroptera: Phyllostomidae) with notes on its karyotype and life history. Occ. Pap. Mus. Zool. La. St. Univ. 38: 1-8.

GELMAN INSTRUMENT CO.

1968 Gelman procedures, techniques, and apparatus for electrophoresis. Ann Arbor, Mich. $78 \mathrm{pp}$.

GENOWAYS, H. H. AND R. J. BAKER

1972 Stenoderma rufum. Mammalian species 18: 1-4. 
GERBER, J. D. AND C. A. LEONE

1971 Immunological comparisons of the sera of certain phyllostomatid bats. Syst. Zool. 20(2): 160-166.

GORNALL, A. G., C. J. BARDAWILL AND M. M. DAVID

1949 Determination of serum proteins by means of the biuret reaction. J. Biol. Chem. 177(2): 751-766.

HANDLEY, C. O., JR.

1959 A revision of American bats of the genera Euderma and Plecotus. Proc. U. S. Natn. Mus. 110: 95-246.

HSU, T. C. AND K. BENIRSHKE, eds.

1967 An atlas of mammalian chromosomes. Vol. 1. New York, SpringerVerlag. 50 folios.

HUNTSMAN, G. R.

1970 Disc gel electrophoresis of blood sera and muscle extracts from some catostomid fishes. Copeia 1970(3): 457-467.

JOHNSON, M. L. AND M. J. WICKS

1959 Serum protein electrophoresis in mammals-taxonomic implications. Syst. Zool. 8(2): 88-95.

1964 Serum-protein electrophoresis in mammals: significance in the higher categories. In Leone, C. A, ed. Taxonomic biochemistry and serology. New York, Ronald Press, pp. 681-694.

JONES, J. K., JR. AND H. H. GENOWAYS

1970 Chiropteran systematics. In Slaughter, B. H. and D. W. Walton, eds. About bats; a chiropteran biology symposium. Dallas, Southern Methodist University Press, pp. 3-21.

JONES, J. K., JR., H. H. GENOWAYS AND R. J. BAKER

1971 Morphological variation in Stenoderma rufum. J. Mammal. 52(1): 244-247.

KIBLISKY, P.

1969 Chromosome patterns of 7 species of leaf-nosed bats of Venezuela (Chiroptera-Phyllostomidae). Experientia 25(11): 1203-1204.

KING, E. J.

1964 Micro-analysis in medical biochemistry by I. D. P. Wootton. [Originally written by E. J. King]. 4th ed. London, J. and A. Churchill. 254 pp.

KINGSLEY, G. R.

1939 The determination of serum total protein, albumin, and globulin by the biuret reaction. J. Biol. Chem. 131(1): 197-200.

KOOPMAN, K. F. AND J. K. JONES, JR.

1970 Classification of Bats. In Slaughter, B. H. and D. W. Walton, eds. About bats; a chiropteran biology symposium. Dallas, Southern Methodist University Press, pp. 22-28.

MC NAB, B. $\mathrm{K}$.

1969 The economics of temperature regulation in neotropical bats. Comp. Biochem. Physiol. 31(2): 227-268.

MANWELL, C. AND C. M. A. BAKER

1970 Molecular biology and the origin of species; heterosis, protein polymorphism and animal breeding. Seattle, University of Washington Press. 394 pp.

MANWELL, C. AND K. V. KERST

1966 Possibilities of biochemical taxonomy of bats using hemoglobin, lactate dehydrogenase, esterases and other proteins. Comp. Biochem. Physiol. $17(3)$ : 741-754.

MILLER, G. S., JR.

1907 The families and genera of bats. Bull. U. S. Natn. Mus. 57: 1-282.

MITCHELL, G. C.

1970 An electrophoretic comparison of hemoglobins in bats. Comp. Biochem. Physiol. 35(3): 667-677. 
MORRIS, B. AND G. RUDGE

1970 Serum proteins in young hedgehogs. J. Zool. 162(4): 461-468. NADLER, C. F.

1968 The serum proteins and transferrins of the ground squirrel stbgenus Spermophilus. Comp. Biochem. Physiol. 27(2): 487-503.

NADLER, C. F., C. E. HUGHES, K. E. HARRIS AND N. W. NADLER

1967 Electrophoresis of the serum proteins and transferrins of Alces alces (elk), Rangifer tarandus (reindeer), and Ovis dalli (Dall sheep) from North America. Comp. Biochem. Physiol. 23(1): 149-157.

NERENBERG, S. T.

1966 Electrophoresis; a practical laboratory manual. Philadelphia, F. A. Davis. $272 \mathrm{pp}$.

PETERSEN, M. K.

1968 Electrophoretic blood-serum patterns in selected species of Peromyscus. Am. Midl. Nat. 79(1): 130-148.

PHILLIPS, C. J. AND J. K. JONES, JR.

1970 Dental abnormalities in North American bats. II. Possible endogenous factors in dental caries in Phyllostomus hastatus. Kans. Univ. Sci. Bull. 48(20): 791-799.

RASMUSSEN, D. I.

1969 Molecular taxonomy and typology. BioScience 19(5): 418-420.

SCHALM, O. W.

1970 Clinical significance of plasma protein concentration. J. Am. Vet. Med. Ass. 157(11): 1672-1675.

SEAL, U. S. AND A. W'. ERICKSON

1969 Hematology, blood chemistry and protein polymorphisms in the whitetailed deer (Odocoileus virginianus). Comp. Biochem. Physiol. 30(4): 695-713.

SILVA TABOADA, G. AND R. H. PINE

1969 Morphological and behavioral evidence for the relationship between the bat genus Brachyphylla and the Phyllonycterinae. Biotropica 1(1): 10-19.

SMITH, J. D.

1972 Systematics of the chiropteran family Mormoopidae. Misc. Publs. Mus. Nat. Hist. Univ. Kans. 56: 1-132.

SOKAL, R. R. AND F. J. ROHLF

1969 Biometry; the principles and practice of statistics in biological research. San Francisco, W. H. Freeman. 776 pp.

TAMSITT, J. R. AND D. VALDIVIESO

1969 Hemoglobin electrophoresis in the systematics of bats (Microchiroptera). Life. Sci. Occ. Pap., R. Ont. Mus. 14: 1-12.

TETS, P. VAN AND I. MCT. COWAN

1966 Some sources of variation in the blood sera of deer (Odocoileus) as revealed by starch gel electrophoresis. Can. J. Zool. 44(4): 631-647.

VALDIVIESO, D., E. CONDE AND J. R. TAMSITT

1968 Lactate dehydrogenase studies in Puerto Rican bats. Comp. Biochem. Physiol. 27(1): 133-138.

VALDIVIESO, D., J. R. TAMSITT AND E. CONDE-DEL PINO

1969 Electrophoretic properties of neotropical bat hemoglobin. Comp. Biochem. Physiol. 30(1): 117-122.

WALKER, E. P.

1968 Mammals of the world. 2d ed. Rev. by J. L. Paradiso. 2 vols. Baltimore, Johns Hopkins Press. 





